\title{
Cleavages and Government in Slovenia and Montenegro
}

\author{
ALENKA KRAŠOVEC AND NEMANJA BATRIĆEVIĆ
}

\section{sciendo}

Politics in Central Europe (ISSN: 1801-3422)

Vol. 16, No. 3

DOI: 10.2478/pce-2020-0027

\begin{abstract}
In this article we identify the factors that contribute to the formation and especially the durability/stability of governments in both Slovenia and Montenegro after they formally introduced multiparty systems and following their democratic transition, with a focus on the effect of cleavages and party system characteristics generally. Although these two polities share several important similarities (small size, common institutional setting during Yugoslav era, aspirations for membership in international organisations etc.), the nature of governments' durability/stability in the democratic era entails distinct differences. While Montenegro stands out in post-socialist Europe as the only case where the ruling party has not been overthrown, Slovenia has been led by many governments composed of different political parties. While it seems that in neither country are the ideological characteristics of the governments able to explain their duration/stability to any important extent, it is obvious that the cleavage structure in the two countries has varied, as has the importance of particular cleavages.
\end{abstract}

Keywords: cleavage, government, duration, political party, democratisation

\section{Introduction}

In a typical modern representative democracy, the government is a branch of power. Discussions about governments often raise issues involving the formation of governments as well as their duration/survival. Government formation lies at the heart of representative politics because it provides the essential connections between ordinary individuals' preferences and the ambitions of politicians, between elections and party competition, and between legislative 
politics, policymaking and governance of the country. Here, the forming of a government is the focal point at which all of these aspects come together in a parliamentary democracy (Laver - Shepsle 1996: 4). Still, the duration or survival of a certain government influences its effectiveness, policy performance and political stability (Browne et al. 1984; Huber 1998; Müller-Rommel 2005).

As Keman (2006: 160) notes, governments in all representative democracies are crucially made up by political parties, and party-based government is the irreducible core of any representative democracy. In the last few decades, scholars have developed theories and models to explain variations in government formation and duration (Warwick 1994; Laver - Shepsle 1996), involving various groups of determinants.

This article aims to explain similarities and/or variations in government formation, highlighting the issue of duration, following the democratic transition of two countries in the area of former Yugoslavia - Slovenia and Montenegro. Both countries share many important characteristics (e.g. a common institutional setting during the Yugoslavia era, a 'triple transition' (political/ economic/socio-territorial), EU and NATO membership aspirations), and have seen similarities in government durability, but differences in their patterns of government formation. Although many country and party characteristics potentially determine the formation and duration of government, this article concentrates on cleavages closely connected to the ideology of parties, and their positions along the left-right ideological spectrum. Unlike many studies of government formation and especially duration (e.g. Grofman 1989; Warwick 1994; Laver - Shepsle 1996; Müller - Strøm eds. 2000; Somer-Topcu - Williams 2008; Conrad - Golder 2010), we will not conduct a robust statistical analysis since we are only investigating a relatively short time period (a maximum of three decades) and just two countries; instead, a simpler analytical and more descriptive approach is used.

\section{Determinants of the Duration of Governments}

As noted, discussions about governments frequently concern questions of government formation, often viewed as a process, but even more of governments' duration or survival in various political and social contexts. When discussing the duration of governments, it is obviously first necessary to know when a new government commenced. It is widely accepted in the literature that a new government emerges with every change in prime minister, the party composition of a government, or legislative period (Browne et al. 1984; Warwick 1994; Müller - Strøm eds. 2000; Blondel et al. 2007). Warwick (1994: 3) warned that while governments indeed change frequently according to these criteria and can thus exhibit a shorter duration or lower stability, different governments can in fact be composed of (largely) the same parties and the same individuals. 
Early studies on government duration primarily explored how different types of electoral systems impact the size and number of parties, while in the 1970s the structural attributes approach flourished, emphasising more the various attributes of parties and governments. Taking the above-mentioned aspects into account, in their review article Grofman and Roozendaal (1997) referred to the findings of many scholars showing that one-party governments last longer than coalition governments and majority governments are more durable than minority ones, while duration also increases with minimal winning coalitions. Saalfeld (2008) added that the number of parties in a government also has a plausible link with its duration; the more parties in government, the greater the scope for interparty disagreement. Still, other research reveals that more ideologically heterogeneous governments are less durable than ideologically more homogeneous ones. However, for decades researchers have continued to disagree on the role played by the ideology of parties or their policy in government duration. As Warwick (1994: 6) stated, although Sartori's analysis of party systems clearly showed that ideological diversity among parties in government is crucial for government duration, its empirical link with government survival was rarely investigated before the mid-1990s, largely due to the difficulty of accurately measuring the ideological positions held by parties.

Browne et al. (1984) seriously contested the structural-attributes approach with the event-thesis approach, accompanied by Ciofi-Revilla's (1984) work. Browne et al. $(1984 ; 1986)$ pointed to the importance of 'events' (like political scandals, international crises, wars, economic changes or illness/death of the prime minister...) which may affect the duration of governments, and called for a shift of scholarly attention from considering the question of how long governments may be expected to endure to questions of when and why they will fall (Browne et al. 1988: 937). Warwick (1994: 10-11) stressed that future progress in this area would require some means of combining the two perspectives, while King et al. (1990) made the first attempt to unify the 'events' approach with the classical (structural-attributes) approach. Later, several unified models were developed that combine the structural-attributes and 'events' approaches (Saalfeld 2008).

Following the democratic transition, studies on government formation and duration have also slowly emerged in Europe's post-socialist countries and generally confirmed much of the evidence from Western Europe, albeit with certain significant differences being identified among the regions, especially in terms of the duration of governments (Blondel et al. 2007; Somer-Topcu Williams 2008; Tzelgov 2011), also because the political context in CEE is sometimes described as being more complex than in Western Europe (Baylis 2007; Grotz - Weber 2012). The structure of cleavages in countries can thus be treated as (part of) the relevant political context, often also with an important impact on the formation of a government and its durability. 


\section{Cleavages, Ideology, Left-Right Ideological Spectrum, and Duration of Governments}

Saalfeld (2008: 348) described how more recent spatial models of government duration had placed considerable emphasis on the relevant parties' policy preferences as predictors of government duration, especially in conjunction with certain features of the party system.

When talking about policy preferences, the researcher cannot overlook the discussion of party ideology and the fact that ideology is driven by cleavages (Pettitt 2014: 60), or that ideology, through configuration of the national party system, is significantly affected by cleavages (Kriesi et al. 2012). Also closely connected to ideology are the generally used notion of the left-right political or ideological spectrum and the concern with party families (chiefly based on ideology), which all helps politicians, the media and voters understand where different parties are located both in relation to each other and to the position of the observer (Freire in Pettitt 2014).

With respect to cleavages, the best known and most referred to approach is Lipset - Rokkan's work from 1967. They argue that religious, cultural, regional and class struggles in society have been translated into deep, long-lasting political divides, and that the ideology of different parties is shaped by these divides or cleavages manifesting as a party system since parties have an expressive function (parties develop rhetorical language to translate the contrasts in the social and cultural structure into demands/pressures or action/inaction) (Lipset - Rokkan 1967). Cleavages have been developed by national and industrial revolutions leading to four cleavages; centre-periphery, State-Church, rural-urban and owner-worker. Lipset - Rokkan (1967) regard these cleavages as being more or less permanent. This means the ideology of today's parties can also be explained by these four cleavages; while parties have come and gone, cleavages have tended to persist through time and generations (Mair 2006). They might even overlap, although it is not necessary that all four cleavages can be found in all countries. This approach tends to neglect a dynamic perspective and has therefore also attracted scepticism about whether we can indeed talk about another, new materialist-postmaterialist or global-local cleavage. Deegan-Krause (2013: 37) notes that these are not the only cleavages possible, yet potential new entrants must clear extremely high barriers if they are to enter the academic literature.

In many empirical analyses, variables capturing the ideological properties of the party system as a whole are shown to have a statistically significant impact on the durability of governments, although interpretations of these findings vary widely (Saalfeld 2008: 348). Yet other studies point to the factor of the ideological or party-family diversity of/within the government. Warwick (1994: 67) contended that his research findings considerably justify the acceptance of lower or minor ideological diversity as a factor contributing to government 
survival. Saalfeld (2008) also reported that in many studies the criterion of ideologically connected parties explained the longer government durability, but there were also some surprising results revealing certain significant risks for the duration of ideologically connected governments.

However, researchers have raised the difficulty of reliably measuring ideological diversity and/or homogeneity. Warwick (1994: 7) explained that it is also possible that the fact researchers continue to disagree on the role played by ideology or policy in government duration may simply be attributed to the difficulties of accurately measuring the ideological positions held by parties.

The left-right ideological positions of parties and ideological diversity/homogeneity within governments is typically measured via expert judgements of party positions, judgements of the public, the positions of party supporters, coding party programmes/manifestos, analysis of political statements and speeches, or legislators' voting patterns (Benoit - Laver 2006). Still, there is also the question of dimensions of this left-right ideological spectrum. While up until the mid-1950s many scholars believed that the ideological spectrum could be organised along the single dimension of left-right policy, the dimension-structured politics in post-revolutionary France, it had become obvious that politics was being organised multidimensionally and that this could also importantly add to the analytical complexity (Warwick 1994; Laver - Shepsle 1996). One question arises: how many dimensions of policy should be used to adequately describe the ideological or policy position of a given political party? One could traditionally talk of at least two ideological or policy dimensions - the economic and cultural/ social values dimension - yet some might also ask if, for instance, European integration or national self-determination etc. dimensions can be added? We must also keep in mind that the ideological/policy positions of parties are fixed at a certain point in time, but may subsequently change (Benoit - Laver 2006: 57).

Also in CEE post-socialist countries one can detect most of the above-mentioned cleavages, although some are less and others more important or exposed than in the more established European democracies, as shown by Deegan-Krause (2013: 45-56). Despite some peculiarities, economic and cultural/social values dimensions can also be applied in the analysis of the ideological left-right positioning of parties, yet studies reveal that attitudes to the communist regime is another important dimension of the cleavage structure in CEE countries (Kitschelt et al. 1999; Casal Bertoa 2014). But the extent and nature of all these cleavages have been varying across CEE countries, as warn Kitschelt (1995) and Whitefield (2002).

\section{Cleavages in Slovenia}

Several scholars (e.g. Vehovar 1996; Fink-Hafner 2001; Zajc - Boh 2004; Prunk 2012) showed in their analyses that during the democratic transition and its con- 
solidation in Slovenia it is generally speaking possible (but not necessarily all at the same time nor for the whole time) to detect the main cleavages identified by Lipset and Rokkan (centre-periphery, State-Church, rural-urban, owner-worker) which in the area of Slovenia were indeed already present before World War II.

More importantly, some or the majority of these cleavages overlap, creating strong polarisation in both the political arena and society (Fink-Hafner 2001). Vehovar (1996) was convinced that the overlapping of the cleavages amounts to a single, all-encompassing cleavage; namely, the traditional-modern ${ }^{1}$ cleavage which may be labelled a cultural cleavage as well. Yet there have also been ideas that one can, in line with pan-European terminology, talk of a libertarian-authoritarian cleavage. Whether it is called a traditional-modern, libertarian-authoritarian, cultural or ideological cleavage, the fact is that this cleavage has continually and vigorously structured the competition among parties in Slovenia and established sharp divisions, even extreme polarisation in society. Such polarisation that would fit with the Roman Catholic Priest Mahnič's pre-World War II notion of the "division of spirits" as a metaphor for the all-embracing conflict ${ }^{2}$ between liberalism and conservatism in politics and society.

In addition and typically for European post-socialist countries, the communism-anticommunism cleavage is also visible, and in Slovenia and it is closely connected with developments during World War II (e.g. Partisans versus the Home Guard or opponents of the occupation forces vs. their collaborators). The resilience and intensity of the cleavage connected with World War II is quite specific in the context of other post-socialist countries since greater attention has been paid to it in former Yugoslavia (Krašovec - Ramet 2017).

Still, for one decade after the democratic transition the cleavage concerning economic issues was less prominent. The country's gradual approach to the economic transition, quite different from many other post-socialist Central and Eastern European countries, and the population's clear demand to preserve the welfare state meant that all parliamentary parties advocated similar social-democratic socioeconomic policies up until the 2004 elections (Fink-Hafner 2006; Stanojević - Krašovec 2011; Kolarič 2012; Johannsen - Krašovec 2017). ${ }^{3}$ Yet, the situation changed at the 2004 elections when the economic-based cleavage became more salient as the electoral winner, the Slovenian Demo-

1 On the other hand, the modern-postmodern cleavage was especially visible at the start of the democratic transition when the parliamentary Green Party successfully represented it in the political arena, but with many divisions in the party the cleavage has lost its prominence. It has regained it lately, mostly due to certain attempts by new entrants in the arena (Fink-Hafner - Novak - Knep 2017).

2 As historically estimated by Prunk (2012) and Vehovar (2012), Slovenian political culture has usually been of a non-consensual variety.

3 In Slovenian society, the population's inclination towards egalitarianism and 'small social/economic differences' has been obvious ever since the democratic transition, although at the end of the 1980s the potential for non-egalitarian inclinations was clearly detected in public opinion polls (Vehovar 1991; Malnar 2012). 
cratic Party, fully entered the conservative camp even though it was originally established as the Social Democratic Party of Slovenia. Several years later, the New Slovenia-Christian Democrats, as a new party with a clear connection to the Slovene Christian Democrats from the 1990s, also started to firmly commit itself to economic liberalism. In the contexts of the economic and fiscal crisis Slovenia faced in the 2009-2014 period and the external pressure of the European Union (EU), European Central Bank (ECB) and International Monetary Fund (IMF) in the early 2010s, almost all parties (regardless of their ideological positions) have accepted more (neo)liberal-oriented socioeconomic reforms. Paradoxically, this means the economic cleavage in the system has again lost its prominence, although the direction of tendencies was then radically different compared with the 1990s. The only obvious exception from this line of recent development is the United Left coalition, later called The Left, first entering the parliamentary arena at the 2014 elections, which has managed to place the conflict between social democratic vs. (neo)liberal socioeconomic policies on the agenda, thereby again raising the profile of the economic cleavage.

However, given that the importance of cleavages can vary over time, the ideological positions held by parties and lines of inter-party competition can also change over time, including due to mergers and/or splits of parties.

While the competition communism-anticommunism line was evident at the first multi-party and democratic elections held in 1990 (Vehovar 1996; Fink-Hafner - Krašovec 2006) and in the bipolar inter-party competition structure, this was soon replaced by a tripolar ideological structure - conservative, liberal, social democratic (Fink-Hafner 2012; Prunk 2012) - and more recently again with a bipolar structure, with all occurring without significant changes to the electoral system or other institutions. Based on many studies, it is obvious that the social democratic pillar was mainly represented by the reformed League of Communists of Slovenia (today's Social Democrats) and the conservative pillar was largely formed by newly established parties more closely connected to more rural areas and Christian values (the Slovenian People's Party and the Slovene Christian Democrats), but more ambiguous for scholars was the position of the newly established Social Democratic Party of Slovenia (today's Slovenian Democratic Party), at least at the start of the 1990s. While some authors claimed that in the early 1990s it was easy to see the Social Democratic Party of Slovenia was a social democratic party, especially with respect to socio-economic issues (Krašovec 1996; Prunk 2012), Pikalo (2000) believes the party always had a strong connection with the Catholic Church. Nevertheless, one can detect more unified stances on the party's position after the mid-1990s (led by Janez Janša - currently still the party's leader), the party first de facto started to turn towards the conservative camp (Zver 2004; Krašovec 2013) to also formally become a member of the conservative party family at the turn of the century. The liberal pillar was represented by the Liberal Democracy of Slovenia (the 
reformed League of Socialist Youth of Slovenia) that grew in prominence in the circumstances of quite a big ideological distance between the two other pillars (Fink-Hafner 2012: 204). ${ }^{4}$ With the demise of the Liberal Democracy of Slovenia soon after the turn of the century, a more or less bipolar ideological structure has mostly returned to Slovenia, although several new successful, but short-lived, parties since 2008 have sought to occupy this position (e.g. Zares - New Politics, List of Zoran Janković - Positive Slovenia, Citizens' List - Party of Gregor Virant, Party of Miro Cerar, Party of Alenka Bratušek, List of Marjan Šarec).

While considering the cultural/social values dimension, one can talk about several main points/issues of differentiation between the parties; the role of the Catholic Church in Slovenian society and politics, abortion, religious instruction in state schools, denationalisation whereby (also) the Catholic Church was entitled to the restitution of expropriated property (including feudal property), the rights of ethnic, sexual and national minorities, and conflicts concerning developments during and also after World War II (Vehovar 1996; Fink-Hafner 2001; Zajc - Boh 2004; Prunk 2012).

On the other hand, the parties' main points/issues of differentiation in the economic dimension up until 1992 was the question of the appropriate form of privatisation and, after the turn of the millennium, state intervention in the economy, the scope of privatisation and questions concerned with the privatisation of the public health, school etc. systems as well as the type of welfare state (Kolarič 2012; Prunk 2012).

In many European countries, EU members or aspirants for membership, a transnational cleavage has also emerged, connected to the stances held by parties, the public and elites on the (development of the) EU. Some researchers say that the old centre-periphery cleavage has indeed been packaged in a new (transnational) form, while others believe this is a genuinely new cleavage that may be expressed differently in various countries, but mainly in the form of Euroscepticism. As found by Lewis - Mansfeldova eds. (2006), Szczerbiak Taggart eds. (2008), Haughton ed. (2009), Lewis - Markowski eds. (2011), Hloušek - Kaniok eds. (2020), Euroscepticism has been present in different forms and different scopes in all post-socialist CEE countries. Slovenia is among the countries where attitude to the EU (or Euroscepticism) has constituted neither an important cleavage nor a line of inter-party competition.

When speaking about party-based Euroscepticism in Slovenia, it should be noted that the entire EU accession period was generally marked by quite a broad consensus within the political elite on the process of joining the EU (Fink-Hafner - Lajh 2003). This broad informal consensus among Slovenian

4 According to Prunk (2012), after 1992 the Liberal Democracy of Slovenia was in economic terms trying to introduce a liberal-market economy while simultaneously preserving the welfare state as well as social cohesion and, on the other hand, it was exposing libertarian values. 
parties on EU membership was visible until the mid-1990s. However, in the context of growing public Euroscepticism since the mid-1990s, under the leadership of the Liberal Democracy of Slovenia, the leading governmental party, in 1997 parliamentary parties decided to deal with the emerging public Euroscepticism, overcome their other differences and conflicts, and sign an Agreement on Co-operation in the EU Accession Process. Only the Slovenian National Party did not sign it. For years, especially at elections, some Euroscepticism was occasionally evident among small and/or marginal parties, yet they were unable to benefit electorally from politicising the topic (Krašovec - Lajh Kustec Lipicer 2006; Krašovec - Lajh 2009). It was only with the eurozone and the subsequent migration crisis that the selective politicisation of EU issues, principally the EU's policies on austerity and migration, also emerged among certain mainstream parties (Haughton - Krašovec 2014; Krašovec - Lajh, 2020). But, generally speaking, one can say that the EU has not been important issue of the inter-party competition line/cleavage in Slovenia.

\section{Parties' ideological positions and the salience of cleavages - public opinion poll data}

As noted, the ideological positions held by parties along the left-right spectrum and thus the ideological diversity/homogeneity within governments are most commonly measured via expert judgements of party positions or judgements made by the public/voters in public opinion polls.

As Table 1 shows, in the selected years (years of parliamentary elections or a year after/before the elections - dependent on the availability of public opinion poll data) certain parties were continually perceived by the public/voters to be centre-left (for example, the Social Democrats, and the Democratic Party of Retired Persons of Slovenia) and others as centre-right (for example, the Slovenian People's Party and New Slovenia). The Liberal Democracy of Slovenia was generally perceived as a centre-oriented party with moderate left leanings, while the Slovenian Democratic Party was in the 1990s mostly seen as centre-right, but since the new millennium more as a right-oriented party. The Slovenian National Party has for much of the time represented an eclectic combination policy of left ${ }^{5}$ and right political values (Krašovec - Haughton 2011: 201), which probably led the public to try to find a balance between left and right positioning of the party. Successful, but generally short-lived new parties have mostly been evaluated by voters as centre-left parties - Zares, Positive Slovenia, Alliance of Alenka Bratušek, Party of Miro Cerar, and the List of Marjan Šarec, while due to the liberal economic policies it had tried to expose the most, the Citizens'

5 In particular, the party's stance on Church-State relations and its evaluation of the role of the partisans in World War II are associated with the left side of the ideological spectrum. 
List has been seen as more of a centre-right party. The (United) Left has been perceived by the public/voters as the most left party of all parliamentary parties (Haughton - Krašovec 2013; 2018; Krašovec - Haughton 2014).

Table 1: Position of political parties along the left-right ideological spectrum in selected years (perception of the public/voters) in \%

\begin{tabular}{|c|c|c|c|c|c|c|}
\hline & $\begin{array}{c}\begin{array}{c}\text { extreme } \\
\text { left* }\end{array} \\
\end{array}$ & left* & centre* & right* & $\begin{array}{c}\text { extreme } \\
\text { right* }\end{array}$ & $\begin{array}{c}\text { Do not know/ } \\
\text { no answer }\end{array}$ \\
\hline \multicolumn{7}{|c|}{1996} \\
\hline DeSUS & 3.5 & 9.9 & 17.9 & 4.5 & 2.6 & 61.6 \\
\hline LDS & 8.3 & 13.3 & 19.7 & 4.1 & 1.9 & 52.7 \\
\hline SD & 13.7 & 12.9 & 13.6 & 3.5 & 1.8 & 54.5 \\
\hline SDS & 1.6 & 4.9 & 19.2 & 10.4 & 7.7 & 56.2 \\
\hline SNS & 5.5 & 5.6 & 13.2 & 8.3 & 11.0 & 56.4 \\
\hline \multicolumn{7}{|c|}{2000} \\
\hline DeSUS & 12.8 & 18.6 & 24.3 & 3.2 & 1.6 & 39.5 \\
\hline LDS & 17.2 & 18.1 & 18.9 & 4.3 & 3.7 & 37.8 \\
\hline NSi & 2.5 & 4.5 & 13.1 & 15.2 & 23.8 & 52.9 \\
\hline SD & 15.1 & 21.4 & 18.4 & 3.7 & 1.6 & 39.9 \\
\hline SDS & 1.9 & 6.3 & 16.7 & 17.2 & 16.3 & 41.6 \\
\hline SNS & 10.0 & 11.8 & 21.9 & 7.0 & 6.3 & 43.0 \\
\hline \multicolumn{7}{|c|}{2005} \\
\hline DeSUS & 4.8 & 11.5 & 26.0 & 7.1 & 2.1 & 45.5 \\
\hline LDS & 15.0 & 18.3 & 16.5 & 3.5 & 1.8 & 44.9 \\
\hline NSi & 1.7 & 6.2 & 11.9 & 13.5 & 19.9 & 46.8 \\
\hline SD & 12.6 & 15.7 & 18.8 & 5.4 & 1.4 & 46.1 \\
\hline SDS & 0.9 & 3.1 & 17.7 & 16.8 & 15.4 & 46.1 \\
\hline SNS & 3.8 & 6.8 & 24.1 & 9.6 & 6.4 & 49.3 \\
\hline
\end{tabular}




\begin{tabular}{|c|c|c|c|c|c|c|}
\hline & $\begin{array}{c}\text { extreme } \\
\text { left* }\end{array}$ & left* & centre* & right* & $\begin{array}{c}\text { extreme } \\
\text { right* }\end{array}$ & $\begin{array}{c}\text { Do not know/ } \\
\text { no answer }\end{array}$ \\
\hline \multicolumn{7}{|c|}{2009} \\
\hline DeSUS & 9.0 & 14.4 & 33.3 & 4.8 & 1.9 & 36.6 \\
\hline LDS & 21.5 & 20.4 & 17.4 & 3.2 & 2.1 & 32.4 \\
\hline $\mathrm{NSi}$ & 5.3 & 6.8 & 13.5 & 14.7 & 23.0 & 49.3 \\
\hline SD & 19.4 & 19.7 & 18.8 & 4.3 & 2.6 & 35.2 \\
\hline SDS & 3.0 & 5.1 & 19.7 & 19.2 & 16.7 & 36.3 \\
\hline SNS & 5.2 & 7.4 & 32.2 & 9.0 & 9.7 & 36.5 \\
\hline \multicolumn{7}{|c|}{2012} \\
\hline DeSUS & 4.2 & 8.8 & 39.7 & 4.5 & 2.5 & 40.3 \\
\hline $\mathrm{NSi}$ & 2.0 & 4.5 & 14.1 & 10.8 & 26.8 & 41.8 \\
\hline SD & 18.6 & 23.6 & 14.8 & 3.7 & 1.4 & 37.9 \\
\hline SDS & 1.8 & 1.9 & 15.3 & 16.0 & 27.1 & 37.9 \\
\hline SNS & 4.7 & 7.4 & 26.7 & 6.1 & 6.7 & 48.4 \\
\hline
\end{tabular}

* Position of parties was assessed on eleven-item scale from 0 to 10 . Combined values of 0 and 1 are treated as 'extreme left', combined values of 2 and 3 are treated as 'left', combined values of 4, 5 and 6 are treated as 'centre', combined values of 7 and 8 are treated as 'right', and combined values of 9 and 10 are treated as 'extreme right'.

Source: Slovenian Public Opinion Polls (Public Opinion and Mass Communication Research Centre at the Faculty of Social Sciences, University of Ljubljana)

Public opinion polls conducted by the Public Opinion and Mass Communication Research Centre at the Faculty of Social Sciences, University of Ljubljana show that the cleavage concerned with developments both during World War II (Partisans vs. the Home Guard or opponents of the occupation forces vs. their collaborators) and the post-war regime has constantly been regarded by the public/voters as one of the most important conflicts, closely followed by the State-Church cleavage. Given the importance of the cleavage, the importance of a conflict between politically left- and right-oriented people also does not come as a surprise; however, it is possible to see that the conflict has intensified considerably; while in $200515 \%$ of respondents saw this conflict as very sharp, in 2013 this share had risen to even $40 \%$. It seems there are at least two reasons for this development: a) after Janez Drnovšek there has not been any political leader able to act as a link in the metric centre of the parties (Fink-Hafner 2012: 
203); and b) the newer bipolarity in the economic dimension (social democratic vs. neoliberal policies) has been overlapping with the traditionally strong libertarian-authoritarian cleavage (Fink-Hafner 2012: 208).

\section{Governments in Slovenia}

Given the PR electoral system, it is no surprise that all governments in Slovenia have entailed coalitions of several parties.

Table 2: Governments in Slovenia (1990-2020)

\begin{tabular}{|c|c|c|c|c|}
\hline Prime Minister & $\begin{array}{l}\text { Parties in } \\
\text { Governments }\end{array}$ & $\begin{array}{l}\text { Start - End } \\
\text { of Governments }\end{array}$ & $\begin{array}{l}\text { Ideological } \\
\text { Characteristics } \\
\text { of Governments } \\
\text { (Perception of } \\
\text { Parties by the } \\
\text { Public) }\end{array}$ & $\begin{array}{l}\text { Characteristics } \\
\text { of Governments } \\
\text { in Relation } \\
\text { to the Main } \\
\text { Cleavage }\end{array}$ \\
\hline Alojz Peterle & $\begin{array}{l}\text { SKD, SKZ, ZS, } \\
\text { SDSS, SDZ, LS }\end{array}$ & 16.5.1990 - 14.5.1992 & $\begin{array}{l}\text { mix/ } \\
\text { heterogeneous }\end{array}$ & $\begin{array}{l}\text { mix/ } \\
\text { heterogeneous }\end{array}$ \\
\hline Janez Drnovšek & $\begin{array}{l}\text { LDS, SDSS, ZS, } \\
\text { SSS, DS }\end{array}$ & 14.5.1992 - 25.1.1993 & homogeneous & $\begin{array}{l}\mathrm{mix} / \\
\text { heterogeneous }\end{array}$ \\
\hline Janez Drnovšek & $\begin{array}{l}\text { LDS, SKD, ZLSD, } \\
\text { SDSS }\end{array}$ & 25.1.1993 - 29.3.1994 & $\begin{array}{l}\text { mix/ } \\
\text { heterogeneous }\end{array}$ & $\begin{array}{l}\mathrm{mix} / \\
\text { heterogeneous }\end{array}$ \\
\hline Janez Drnovšek & $\begin{array}{l}\text { LDS (+ Z-ESS, } \\
\text { DS, SSS)*, SKD, } \\
\text { ZLSD }\end{array}$ & 29.3.1994 - 31.1.1996 & $\begin{array}{l}\text { mix/ } \\
\text { heterogeneous }\end{array}$ & $\begin{array}{l}\text { mix/ } \\
\text { heterogeneous }\end{array}$ \\
\hline Janez Drnovšek & $\begin{array}{l}\text { LDS (+ Z-ESS, } \\
\text { DS, SSS)*, SKD }\end{array}$ & 31.1.1996 - 27.2.1997 & $\begin{array}{l}\operatorname{mix} / \\
\text { heterogeneous }\end{array}$ & $\begin{array}{l}\text { mix/ } \\
\text { heterogeneous }\end{array}$ \\
\hline Janez Drnovšek & $\begin{array}{l}\text { LDS, SLS, } \\
\text { DeSUS }\end{array}$ & 27.2.1997 - 7.6.2000 & $\begin{array}{l}\mathrm{mix} / \\
\text { heterogeneous }\end{array}$ & $\begin{array}{l}\mathrm{mix} / \\
\text { heterogeneous }\end{array}$ \\
\hline Andrej Bajuk & SLS + SKD, SDS & 7.6.2000 - 30.11.2000 & homogeneous & \\
\hline Janez Drnovšek & $\begin{array}{l}\text { LDS, ZLSD, SLS } \\
+ \text { SKD, DeSUS, } \\
\text { SMS }\end{array}$ & 30.11.2000 - 19.12.2002 & $\begin{array}{l}\operatorname{mix} / \\
\text { heterogeneous }\end{array}$ & $\begin{array}{l}\text { mix/ } \\
\text { heterogeneous }\end{array}$ \\
\hline Anton Rop & $\begin{array}{l}\text { LDS, ZLSD, SLS } \\
+ \text { SKD, DeSUS, } \\
\text { SMS }\end{array}$ & 19.12.2002 - 4.4.2004 & $\begin{array}{l}\mathrm{mix} / \\
\text { heterogeneous }\end{array}$ & $\begin{array}{l}\operatorname{mix} / \\
\text { heterogeneous }\end{array}$ \\
\hline Anton Rop & $\begin{array}{l}\text { LDS, ZLSD, } \\
\text { DeSUS, SMS }\end{array}$ & $4.4 .2004-3.12 .2004$ & homogeneous & homogeneous \\
\hline Janez Janša & $\begin{array}{l}\text { SDS, NSi, SLS, } \\
\text { DeSUS }\end{array}$ & $3.12 .2004-21.11 .2008$ & homogeneous & homogeneous \\
\hline Borut Pahor & $\begin{array}{l}\text { SD, Zares, LDS, } \\
\text { DeSUS }\end{array}$ & 21.11.2008 - 9.5.2011 & homogeneous & homogeneous \\
\hline Borut Pahor & SD, Zares, LDS & 9.5.2011 - 27.6.2011 & homogeneous & homogeneous \\
\hline Borut Pahor & SD, LDS & 27.6.2011 - 10.2.2012 & homogeneous & homogeneous \\
\hline Janez Janša & $\begin{array}{l}\text { SDS, NSi, SLS, } \\
\text { DeSUS, DL }\end{array}$ & 10.2.2012 - 23.1.2013 & homogeneous & $\begin{array}{l}\mathrm{mix} / \\
\text { heterogeneous }\end{array}$ \\
\hline Janez Janša & $\begin{array}{l}\text { SDS, NSi, SLS, } \\
\text { DeSUS }\end{array}$ & $231.2013-20.3 .2013$ & homogeneous & homogeneous \\
\hline
\end{tabular}




\begin{tabular}{|l|l|l|l|l|}
\hline Alenka Bratušek & $\begin{array}{l}\text { PS (ZaAB), } \\
\text { DeSUS, DL, SD }\end{array}$ & $20.3 .2013-18.9 .2014$ & homogeneous & homogeneous \\
\hline Miro Cerar & $\begin{array}{l}\text { SMC, SD, } \\
\text { DeSUS }\end{array}$ & $18.9 .2014-13.9 .2018$ & homogeneous & homogeneous \\
\hline Marjan Šarec & $\begin{array}{l}\text { LMŠ, SD, SMC, } \\
\text { SAB, DeSUS }\end{array}$ & $13.9 .2018-13.3 .2020$ & homogeneous & homogeneous \\
\hline Janez Janša & $\begin{array}{l}\text { SDS, SMC, NSi, } \\
\text { DeSUS }\end{array}$ & $13.3 .2020-$ & $\begin{array}{l}\text { mix/ } \\
\text { heterogeneous }\end{array}$ & $\begin{array}{l}\text { mix/ } \\
\text { heterogeneous }\end{array}$ \\
\hline
\end{tabular}

Source: Krašovec - Krpič (2019a: 237) and own analysis of authors

Abbreviations of party names: SKD = Slovenski krščanski demokrati/Slovene Christian Democrats; SLS (SKZ) = Slovenska ljudska stranka/Slovene People's Party; SLS + SKD = Slovenska ljudska stranka in Slovenski krščanski demokrati/Slovene People's Party+Slovene Christian Democrats (parties merged in April 2000, but several months later the party changed its name to SLS) ZS = Zeleni Slovenije/Greens of Slovenia; SDZ = Slovenska demokratična zveza/Slovene Democratic Union; LS = Liberalna stranka/Liberal Party; DS = Demokratična stranka/Democratic Party; SSS = Socialistična stranka Slovenije/Socialist Party of Slovenia; LDS = Liberalno demokratska stranka/Liberal Democratic Party, since 1994 Liberal Democracy of Slovenia; SDS(S) = Socialdemokratska stranka Slovenije/Social Democratic Party of Slovenia, since 2003 Slovenian Democratic Party; Z-ESS = Zeleni - Ekološko-socialna stranka/Greens - Ecological-Social Party; DeSUS = Demokratična stranka upokojencev Slovenije/Democratic Party of Retired Persons of Slovenia; ZL(SD) = Združena lista (socialnih demokratov)/United List (of Social Democrats), since 2005 Socialni demokrati/Social Democrats (SD); SMS = Stranka mladih Slovenije/Youth Party of Slovenia; NSi = Nova Slovenija/New Slovenia; Zares - Nova politika/For Real - New Politics; DL = Državljanska lista/ Citizens' List; PS = Pozitivna Slovenija/Positive Slovenia; ZaAB = Zavezništvo Alenke Bratušek/Alliance of Alenka Bratušek, later Party of Alenka Bratušek (SAB); SMC = Stranka Mira Cerarja/Party of Miro Cerar, since 2015 Party of Modern Centre; LMŠ = Lista Marjana Šarca/List of Marjan Šarec

Governments that concluded their term due to regular elections are shown in bold.

* In March 1994, LDS merged with Z-ESS and parts of DS and SSS.

Ideologically speaking, one can talk about two patterns of coalition formation: ideologically mixed or homogenous (Zajc 2009; Krašovec - Krpič 2019b). The first type of coalition occurred under PM Drnovšek and the LDS-leadership from 1992 to 2004. After the 1992 elections, PM Drnovšek formed an ideologically heterogeneous coalition of centre-left and centre-right parties (namely, the old (transformed) and newly established parties) for two reasons. First, he aimed to overcome the well-known ideological bipolarisation in Slovenia already observable in the pre-war period (Zajc 2009; Fink-Hafner 2012). Second, he included a newly established centre-right oriented party (SKD) in his second government to ensure its greater legitimacy abroad (Prunk 2006: 253). Further, the very small and also newly established SDS was only included in the coalition because the SKD needed an excuse for its voters as to why it had cooperated with the transformed parties (Krašovec - Krpič 2019b). Later, Drnovšek followed the pattern of ideologically mixed governments, also because the opposition then remained ideologically diverse as well, and he could frequently rely on de facto support from the opposition.

Since the 2004 elections, the governmental coalitions were much more ideologically homogenous and alternation between ideologically more coherent 
coalitions (centre-left or centre-right) has become the rule, and this development has probably also been a result of the more bipolar structure of Slovenian politics, that is, instead of a three-polar structure, like it used to be after the mid-1990s (Fink-Hafner 2012; Krašovec - Krpič 2019b).

Three more points must be made while considering the ideological characteristics of governments in Slovenia. First, the Demos coalition is generally described as a homogeneous one. This is mostly because the newly established parties formed it, but Demos was indeed ideologically very heterogeneous, similar to several other broad coalitions, new movement parties or anti-communist umbrella organisations in CEE countries at the start of the democratic transition (Ágh 1998; Prunk 1992, 2012; Zajc 2004). Still, Demos cannot be simply classified as an ideologically heterogeneous coalition. It is more appropriate to describe it as a pro-independence/transitional coalition where the newly established parties formally joined forces to accelerate the democratic transition and the process of gaining independence (Krašovec-Krpič 2019b). Second, it is obvious that DeSUS holds the greatest coalition potential, but it is largely seen as an interest-group or a single-issue party. What is important is that over time, the party's position in the formation of governments has changed from a supplementary role to a more decisive one in forming both centre-left and centre-right coalitions (Krašovec - Krpič 2019b: 490), despite the public/voters having mainly evaluated it as a centre-left party. Third, in terms of ideological properties of governments, one cannot escape a certain level of simplification, e.g. governments led by Janša (2004-2008 and 2012-2013) are characterised as ideological homogeneous since only the quite small centre-left DeSUS participated in those governments.

If we try to link the findings concerning the ideological properties of Slovenian governments and cleavage structure with their duration/stability, it is hard to detect any obvious connection between these two characteristics since all Slovenian governments, whether ideologically mixed or homogenous, except for Janša's first government, experienced such internal turmoil that they were unable to complete the normal 4-year legislative period. However, while in the 1990s ideologically mixed and unstable governments operated until the new regular elections, recently under more ideologically homogeneous (centre-left) governments early elections were held (e.g. governments led by Pahor, Bratušek and Cerar).

\section{Cleavages in Montenegro}

The decisive triumph of the League of Communists of Montenegro at the first democratic election held in December 1990 marked the start of the long reign of its renamed successor - the Democratic Party of Socialists (DPS). Today, Montenegro remains the only post-socialist country in Europe to be ruled by 
the same party since the introduction of political pluralism. This unmatched government stability even during remarkably turbulent times requires a deeper analysis of the role played by cleavages in government formation. While the three-decades-long dominance of a single party can only be explained by a range of social factors, a consensus has emerged in the literature that successful monopolisation of the statehood/nationhood issue, around which the dominant cleavage has emerged, represents a necessary condition for the longevity of the DPS (see Bieber 2013; Džankić 2013; Vuković 2015; Komar Živković 2016).

Whereas Slovenia is recognised as an early 'regional success', the Montenegrin transition from an authoritarian to a democratic system was neither short nor smooth. The incapacity of former communist elites to resolve important political and economic issues has diverted society towards the constant production of enemies defined in ethnic terms and successfully impeded the development of one of the most defining characteristics of democratic regimes - ideology-based linkages between the citizens and the parties (Kitschelt 2000). If one relies on Lipset - Rokkan (1967) to classify the emergence of the dominant cleavage in Montenegro, it would most reasonably be seen, in a wider sense, as the centre-periphery cleavage. Namely, although designations of "centre" and "periphery" have changed depending on the state formation at hand, the issues of self-determination, nation-building and reaction to the intense cultural standardisation of ethnically distinct groups are essential for understanding Montenegrin politics over the last 30 years.

While Montenegro represents a classical example of a predominant party system in Sartori's (2005) classification, the landscape of the party space has varied over time. Without significant changes to the electoral system, the Montenegrin multiparty system has shifted from being extremely fragmented to extremely polarised, and back (see Vuković - Batrićević 2020). These shifts, however, appear to have nothing to do with ideological diversification of the political space as ideology remains a poor predictor of the behaviour of both parties and voters. In simple terms, one can hardly find a single example of a successful coalition that may be considered principled from an ideological standpoint. Instead, Montenegro's long transition has been marked by patterns of political competition that crystallised voter alignment (Bartolini - Mair 2007) in reference to the historical dilemma of whether Montenegrins constitute a distinct nation and have the right to decide the faith of their own state. In 1918, the overwhelming consensus among people in Montenegro to enter a shared South Slavic state was overshadowed by a dispute over the manner in which the unification should be carried out. Contrary to the wishes of the Montenegrin dynasty in exile, which sought to unite with other constituent nations on an equal footing, the proponents of unconditional unification with Serbia held 
an illegitimate Podgorica Assembly whose main decisions were to abolish the Montenegrin state and assimilate its people ${ }^{6}$.

The Montenegrin transition to a democracy started with an intra-elite coup ("anti-bureaucratic revolution") in 1989 that intended to secure the continuation of Communist Party rule with strong nationalist overtones (Darmanović 2003). The new elite replaced ideology as the main pillar of the ruling party with the mere desire for political survival and obscured the lack of policy solutions by adhering to the ethno-religious mobilisation ${ }^{7}$ that had emerged across region (Džankić 2013). Running on aggressive stance against ethnic minorities (Albanians, Bosniaks, Muslims), the DPS won an absolute majority of seats in all three parliamentary elections between 1990 and 1996. During this period, Montenegrin cabinets essentially functioned as one-party governments ${ }^{8}$, thereby making the opposition the more competitive side of the party system. The first attempt to create a coalition across the national divide came in 1996 when the pro-Montenegrin Liberal Alliance of Montenegro (LAM) and pro-Serbian national-conservative People's Party (PP) decided to 'freeze their programmatic differences' and attempt to inflict the first electoral defeat on the DPS. However, despite the relationship between parties being decent, the cooperation failed to produce the increase in electoral support needed to overthrow the DPS (Goati 2013).

To the extent ideology was at all relevant to voters unused to a 'market of ideas', DPS could have been classified as the centre-left (social-democratic) party. The ruling party's thin ideological content favoured private over state ownership, despite strong references to social redistribution in favour of the most vulnerable. On the opposition side, the conservative PP and liberal LAM were significantly more reserved towards 'big government'. Notwithstanding the principal adherence to democratisation and a market-based economy, each party generally mobilised its voters along identity lines (Darmanović 2007: 85-88). The desire to maintain the support of the Orthodox majority required DPS to leave the politically sensitive national question unresolved and embrace a "policy of ambiguity" under which Montenegrins existed as a "national homo duplex" (Darmanović 1992; Morisson 2009). In a similar fashion, PP did not

6 The Assembly ended with the vice-president's famous remark: "I urge you, gentleman, to set aside the history of Montenegro. Its political history, however, is divided in two parts: until yesterday, and since yesterday. We are no longer Montenegrins, but Serbs" (Popović 2011: 145).

7 Despite adopting nationalist rhetoric from Belgrade, DPS opted for proportional representation as the mode for the multiparty election, with a medium electoral threshold $(3 \%-4 \%)$. This quite inclusive electoral formula remains the most constant feature of the Montenegrin electoral system to date. Insistence on proportional representation is clearly rooted in the specific demographic composition of Montenegro and the country's ethnically heterogeneous structure (Pavićević et al. 2007).

8 Although DPS created a wider "government of national unity" during wartime (1993-1996) with three opposition parties (LAM, SDP, PP), the overwhelming domination of DPS made this coalition function effectively as a one-party cabinet (Goati - Darmanović, 2015). 
negate the existence of the Montenegrin nation, while strongly advocating for the development of a "Serbian consciousness". The third largest party in the Montenegrin parliament at the time, LAM, was a truly liberal party advocating a liberal democracy, a free market and respect for the human rights of all citizens, regardless of their ethnic and religious background. However, together with the Social-democratic Party (SDP), the party was best known for its fierce support for the independent Montenegrin state (Goati - Darmanović 2015) as it believed the 'third Yugoslavia' was nothing more than a 'Greater Serbia' with extended sovereignty over Montenegro.

The defining moment in development of the Montenegrin party system was the 1997 party split that occurred in the DPS. An open conflict escalated during the presidential election between the party's president and the conservative Milošević-loyalist Momir Bulatović and the "pro-Western reformist" vice-president Milo Đukanović. These, arguably, the first truly competitive elections, marked the beginning of a short period in which the existing ethno-religious cleavage was overshadowed by the divide over the question of support for the regime of Slobodan Milošević ${ }^{~}$ (Džankić 2013). Once a faction loyal to Belgrade had formed the Socialist People's Party (SPP), political unity within the Orthodox population was a matter of the past. This divide, however, was functional in nature as the initial clash between Belgrade and Podgorica arose from the economic consequences of the international sanctions and later intensified amidst the growing debate on Montenegrin independence (Vuković 2015). A reformist coalition brought together DPS, SDP, LAM and PP, and steered the DPS in the direction of economic and political reforms (Beiber 2013). The increasingly dysfunctional state union (culminating in 1999 in the Kosovo war), disadvantageous economic position of Montenegro, distinctive transnational priorities as well as the lack of recognition of cultural/identity specificities started to force the response of 'peripheral' Montenegro to the pressures of the centralising machinery of Belgrade ${ }^{10}$.

However, it was only after the fall of Milošević (2000) that a window of opportunity opened for a full resurfacing of the ethnic cleavage between groups holding a distinct understanding of Montenegrin national identity (Darmanović 2006: 91-94). The newly emerged conflict over statehood conditioned the restructuring of the entire system of party alignments (Lipset - Rokkan 1967: 41). The shift in paradigm from democratisation to statehood/nationhood made PP

9 Interestingly, unlike in other ex-Yugoslav republics, explicitly anti-communist parties were less prominent in Montenegro. While some parties (LAM and SDP) were critical of DPS as a successor to the League of Communists, this attitude was not directed at former communist elites. The most prominent anti-communist stance was held by the national-conservative PP (Beiber 2013).

10 The freshly elected Montenegrin elites in 1998 were openly belittled by the selection of Momir Bulatović, loser of the presidential election, as the prime minister of the Federal Government. Continued marginalisation within the federal structure fuelled secessionist tendencies in Montenegro and legitimised the pursuit of statehood/nationhood by the otherwise ambivalent DPS. 
leave the government and join the freshly formed unionist camp with SPP and the Serbian People's Party (SNS). On the other side, DPS solidified its coalition with the pro-independence SDP and secured 'outside' support from LAM ${ }^{11}$. The restructuring of political forces led Pavlovic (2003:94) to conclude that the political atmosphere after 2000 "greatly resembled that of 1918 when the issue of unification of Montenegro with Serbia was a hot political topic". In 2001, DPS officially declared it would pursue a renewal of Montenegro's independence, demanding a reconstruction of the meaning of "Montenegrin" and "Serb" categories as distinct and intrinsically tied to independence and unionist camps, respectively (Džankić 2013).

For an entire decade (1996-2006) the patterns of political competition in Montenegro closely resembled a two-party system. Party lists organised around DPS and SPP managed to marginalise other political actors and win $93 \%$ of the seats in 1998 and $92 \%$ in 2002. Still, during this period the vast majority of governments were extensively large and involved more political parties than necessary in order to build a wider consensus and provide stability in the face of the upcoming referendum on independence. Nonetheless, despite the relatively wide and heterogeneous nature of governments an invitation to join in the government was never issued to parties which had rejected the idea of Montenegrin independence.

\section{Post-referendum Montenegro}

Regardless of the narrow margin (just $0.5 \%$ above the required threshold) in the 2006 independence vote, many assumed that once the statehood issue had been "taken of the table", the socio-economic cleavage would emerge (Goati 2008) and parties would have to "adapt to new circumstances after the resolution of the statehood issue" (Džankić 2013: 415). Yet, the short-sightedness of this presumption became apparent when DPS achieved landslide victories in the three elections following the referendum (2006, 2009, and 2012). Electoral wins even in the face of a significant worsening of the economic conditions would hardly be explainable had the socio-economic cleavage emerged as a substitute for the ethnic one. Instead, 14 years since the statehood issue has been formally resolved, the main political parties continue to legitimise their political decisions with strong reference to pre-referendum stances.

The ruling party, DPS, takes on the role of the 'protector' of Montenegrin sovereignty and actively engages in creating unambiguous nation-building policies like the adoption of new state symbols, the proclamation of Montenegrin as the country's official language, as well as the recent attempt to re-establish

11 At the 2001 elections a DPS-led coalition won, but did not secure an absolute majority of seats. The coalition was then supported by LAM, which rejected the offer to officially enter the coalition. This remains the sole example of a 'minority government' in Montenegrin politics (Goati - Darmanović 2015). 
the Montenegrin Orthodox Church (Vuković - Batrićević, 2020). On the other hand, pro-Serbian opposition parties led by the Democratic Front (DF) ${ }^{12}$ deny the legality of the referendum, negate the historical legitimacy of national symbols, and continue to suggest that the independent Montenegro is nothing more than an intermezzo between two shared states with Serbia ${ }^{13}$. In that sense, the persistence of the identity cleavage may be seen as a direct product of resistance to the central authority's intense nation-building by the ethnically/culturally distinct segments of populations which seek to 'preserve the traditional identity of Montenegro'. The fact that the Serbian national minority is geographically concentrated in less economically developed, more conservative and rural areas means this cleavage is further reinforced by other dimensions of conflict. The overlapping of multiple potential cleavages fosters the pro-Serbian opposition's interpretation of the cleavage as a struggle between advanced areas of the 'centre' and the backward 'periphery'.

With respect to government formation, despite the high levels of fragmentation ${ }^{14}$ the statehood cleavage has not made the Montenegrin party system dysfunctional (Goati - Darmanović 2015). It divides parties into two blocs and fosters easier coalition-building by reducing the 'degrees of freedom' as it 'prohibits' cross-cleavage interaction and absorbs potentially cross-cutting issues. Two of the most important political issues since the last parliamentary election - the country's accession to NATO (see Banović 2016) and the attempt to change the status of the Montenegrin Orthodox Church - have also led to homogenisation around statehood/nationhood. Under the narrative of the 'prolonged referendum', both the NATO accession and the reclaiming of church properties confiscated after the 1918 Serbian annexation of Montenegro, have been viewed as another step towards securing the state's sovereignty (Pavlović 2008). The legislative coalition in support of these policies is practically indistinguishable from the former independence movement.

12 Democratic Front is not a party itself, but a permanent alliance between New Serbian Democracy (NSD) and Movement for Change (MC) that were created leading up to the 2012 parliamentary election. Following its electoral success in 2012 (22.8\%), the alliance has been expanded to include other parties, most notably the Democratic People's Party (DPP).

13 The most notable negation of state symbols includes MPs from the pro-Serbian Democratic Front refusing to stand during intonation of the national anthem.

14 At the 2016 election, a total of 17 parties entered, gaining seats from 10 party lists. The Montenegrin party system experienced significant fragmentation between the 2012 and 2016 elections. After the breakup of the almost 20-year-long coalition between DPS and SDP in 2015, a faction of SDP led by its vice-president Ivan Brajović defected by creating a new party - Socialdemocrats (SD). Intra-party conflicts within SPP led to two new parties - the Democrats (DEM) and the Democratic People's Party (DPP) - while the former leader of DF parted ways with the alliance and established Demos. Soon afterwards, a faction of Demos led by its vice-president Goran Danilović left the newly established party to create a separate political organisation - United Montenegro (UCG). Finally, a number of senior officials from the pro-Montenegrin party Positive Montenegro defected to form a new political organisation in 2015 - United Reformist Action (URA) (see Stankov 2019). 
Parties' ideological positions and the salience of cleavages in Montenegro - public opinion poll data

Empirical evidence supports the claim that government formation, as well as the citizen-party linkage, in contemporary Montenegro do not occur along "classic" left-right lines. The survey data allow us to compare the distance between parties and voters on a 'traditional' left-right versus identity scale (pro-Montenegrin - pro-Serbian).

Table 3: Position of political parties and voters in Montenegro along the leftright ideological and national identity spectrum (0-10)

\begin{tabular}{|l|c|c|c|c|c|c|}
\hline & \multicolumn{3}{|c|}{ Left-right scale } & \multicolumn{3}{c|}{ National identity scale } \\
\hline & Voters & Party & Diff. & Voters & Party & Diff. \\
\hline Democratic Party of Socialists & 5 & 7 & 2 & 2 & 2 & 0 \\
\hline Democratic Front & 6 & 7 & 1 & 7 & 9 & 2 \\
\hline Democrats of Montenegro & 5 & 4 & 1 & 5 & 5 & 0 \\
\hline United Reformist Action & 3 & 4 & 1 & 4 & 4 & 0 \\
\hline Socialdemocratic Party & 5 & 4 & 1 & 2 & 0 & 2 \\
\hline Socialist People's Party & 5 & 4 & 1 & 7 & 8 & 1 \\
\hline Socialdemocrats & 4 & 7 & 3 & 1 & 1 & 0 \\
\hline Average & 4.71 & 5.29 & 1.43 & 4.00 & 4.14 & 0.71 \\
Deviation & 0.95 & 1.6 & 0.79 & 2.45 & 3.44 & 0.95 \\
\hline
\end{tabular}

Source: Comparative Study of Electoral Systems (CSES) 2016

The data clearly show there is no significant difference in ideology among the voters, who mostly concentrate in the centre-left. Although nominally social-democratic, DPS has been evaluated as being on the right due to its support for privatisation and the free market. There is almost no ideological distance between voters of the ruling DPS and the two largest opposition parties/coalitions (Democrats and Democratic Front), consistent with experts assessing DPS and DF to be perfectly ideologically congruent. On the other hand, the largest ideological distance is observed between the 18-year-long-coalition partners (DPS and SDP) that are located on opposite sides of the ideological spectrum. The biggest discrepancy between voters and the party of choice is seen in the case of SD, a defected faction of SDP. Based on expert judgements, this party is located on the right while its voters, on average, remain in the ideological positions of the former party, suggesting that the party split was not driven by ideology.

In contrast, we observe significant deviation among parties with respect to the issue of national identity. Ten years after the referendum, there was still an extremely wide gap between the parties that once led the independence movement (DPS and SDP/SD) and parties which represented the backbone of 
Table 4: Governments in Montenegro (2006-2020)

\begin{tabular}{|l|c|c|c|c|}
\hline Prime Minister & $\begin{array}{c}\text { Parties in } \\
\text { Governments }\end{array}$ & $\begin{array}{c}\text { Start - End of } \\
\text { Governments }\end{array}$ & $\begin{array}{c}\text { Ideological } \\
\text { Characteristics } \\
\text { of Governments } \\
\text { (Public } \\
\text { Perception) }\end{array}$ & $\begin{array}{c}\text { Characteristics } \\
\text { of Governments } \\
\text { in Relation } \\
\text { to the Main } \\
\text { Cleavage }\end{array}$ \\
\hline Željko Šturanović* & DPS,SDP,DUA & $\begin{array}{c}22.10 .2007- \\
31.01 .2008\end{array}$ & $\begin{array}{c}\text { mix/ } \\
\text { heterogeneous }\end{array}$ & homogeneous \\
\hline Milo Đukanović & DPS,SDP,DUA & $\begin{array}{c}31.01 .2008- \\
29.02 .2009\end{array}$ & $\begin{array}{c}\text { mix/ } \\
\text { heterogeneous }\end{array}$ & homogeneous \\
\hline Milo Đukanović & DPS,SDP,DUA,BS & $\begin{array}{c}29.02 .2009- \\
23.12 .2010\end{array}$ & $\begin{array}{c}\text { mix/ } \\
\text { heterogeneous }\end{array}$ & homogeneous \\
\hline Igor Lukšić & DPS,SDP,DUA,BS & $\begin{array}{c}23.12 .2010- \\
14.10 .2012\end{array}$ & $\begin{array}{c}\text { mix/ } \\
\text { heterogeneous }\end{array}$ & homogeneous \\
\hline Milo Đukanović & DPS,SDP,HGI,BS & $\begin{array}{c}14.10 .2012- \\
02.06 .2015\end{array}$ & $\begin{array}{c}\text { mix/ } \\
\text { heterogeneous }\end{array}$ & homogeneous \\
\hline Milo Đukanović & DPS,SDP,SD,HGI,BS & $\begin{array}{c}02.06 .2015- \\
17.02 .2016\end{array}$ & $\begin{array}{c}\text { mix/ } \\
\text { heterogeneous }\end{array}$ & homogeneous \\
\hline Milo Đukanović & DPS,SD,HGI,BS & $\begin{array}{c}17.02 .2016- \\
17.06 .2016\end{array}$ & $\begin{array}{c}\text { mix/ } \\
\text { heterogeneous }\end{array}$ & homogeneous \\
\hline Milo Đukanović** & DPS,SD,HGI,BS, & $\begin{array}{c}17.06 .2016- \\
17.10 .2016\end{array}$ & $\begin{array}{c}\text { mix/ } \\
\text { heterogeneous }\end{array}$ & heterogeneous \\
\hline Duško Marković & DPS,SD,DUA,HGI,BS & $28.11 .2016-$ & $\begin{array}{c}\text { mix/ } \\
\text { heterogeneous }\end{array}$ & homogeneous \\
\hline
\end{tabular}

Source: Casal Bértoa, Fernando (2020): Database on WHO GOVERNS in Europe and beyond, PSGo

Abbreviations of party names: DPS = Demokratska partija socijalista/Democratic Party of Socialists; SDP = Socijaldemokratska partija/Socialdemocratic Party; SD = Socijaldemokrate/ Socialdemocrats; BS = Bošnjačka stranka/ Bosniak Party; DUA = Demokratska unija Albanaca/Democratic Union of Albanians; $\mathrm{HGI}=$ Hrvatska građanska inicijativa/Croatian Civic Initiative. Ethnic parties are shown in bold.

* Željko Šturanović resigned in 2008 due to poor health.

** The Government of Electoral Confidence formed in June 2016 was a caretaker government. The cabinet included five ministers from opposition parties or independents.

the union movement (DF and SPP). On the dimension of national identity, the average distance between voters and their respective parties is half the size as in case of left-right. Evidently, ideology continues to be a poor substitute for the cleavage that emerged around the statehood/nationhood issue since people continue pointing to nationality as the most important collective category of their self-image (83\%), significantly ahead of class belonging.

Part of the explanation may lie in the uninformative nature of the policy packages offered by parties, which curtails the ability of voters to map their socio-economic preferences onto a single left-right spectrum. When parties are incentivised to compete only for support within an ethnically defined bloc (Horowitz 1993), voters are likely to hold the expectation of in-group favouritism and distrust in the universal distribution of policy benefits. Although data on the meaning of the left-right scale is lacking in the case of Montenegro, we can nonetheless deduce to what extent ideological orientation is a reliable reflection of voters' attitudes. Again, it seems that an individual's location on the 
left-right spectrum is completely detached from their attitudes to economic redistribution ${ }^{15}$ because ideological position is identical among those who strongly agree with the government's active efforts to reduce inequalities $(M=5.37)$, those who only partially agree $(M=5.38)$ and those who disagree with the idea of 'big government' $(M=5.32)$. Moreover, almost half $(46 \%)$ the respondents who declared a strong preference for economic redistribution self-positioned themselves on the right side of the ideological spectrum (CSES 2016).

Based on survey evidence, it is hardly a surprise that conflict over statehood/nationhood has effectively side-tracked all of the 'classic' ideological differences and allowed for a significant level of ideological heterogeneity in each government since independence has been renewed. Obviously, due to being a typical case of a predominant party system, the ideological mixture is still heavily in favour of the policy preferences of the centre-right DPS ${ }^{16}$. Yet, despite the disproportional size of the parties that make up the governments, public displays of ideological disagreement between DPS and SDP were fairly common, especially with respect to the issue of privatising state-owned companies. Still, the majority of Montenegrin governments (see Table 4) have shown some instability, although they have been able to finish (or come close to) their full legislative terms without early elections, despite their mixed/ heterogeneous character.

What enables ideological heterogeneity to not exert a negative effect on government stability in Montenegro? Put simply, when the political status of a state is contested, programmatic disputes become secondary. While most parties formally and by name have positioned themselves along the classic left-right spectrum, these labels have remained declaratory and without substance. It is, therefore the nature of the dominant cleavage that has kept left-right ideology subordinated to differences with respect to the question of identity (Beiber 2013). The fact that economic platforms and welfare policy have never been central issues of electoral campaigns has allowed for long-lasting coalitions between right, left and ethnic minority parties. Clearly, the stability of the governing coalitions in Montenegro is consistently provided by homogeneity with regard to the main cleavage. With the exception of the short-lived caretaker government in 2016, there has been no government involving parties that have rejected Montenegrin statehood and nationhood.

15 The survey item measuring preferences regarding redistribution in the 2016 Montenegrin National Election Study asks respondents to what extent they agree with the statement that "government should take active measures to reduce income inequalities".

16 Based on the database of WHO GOVERNS in Europe and beyond, PSGo (Casal Bértoa 2020), with the exception of 2016, the Marković government which included many cabinet members who, despite the public's perception, are formally independent, all other cabinets have been composed of approximately $75 \%$ DPS members. 


\section{Conclusion}

Some previous research indicates that the ideological properties of governments can affect their durability whereby more ideologically heterogeneous governments tend to be less durable than homogeneous ones. In this article, we have attempted to explain differences between the two former Yugoslav republics of Slovenia and Montenegro with regard to the nature of government formation and especially durability/stability. We focused on the role played by cleavages and ideological properties in explaining outcomes in an institutional environment of similar PR electoral systems.

Despite several limitations, our findings give evidence that ideological homogeneity/heterogeneity has in fact had not impacted government durability in either Slovenia or Montenegro. While the ideological properties of Slovenian governments have varied over time, this variation seem to hold no consequences for government durability/stability. Regardless of their ideological properties, Slovenian governments have typically been marked by considerable instability. In contrast, Montenegrin governments have consistently been ideologically heterogeneous and yet, like in Slovenia, they may be denoted with similar levels of stability as the governments in Slovenia.

Hence, we maintain the primary reason behind the similar outcomes in terms of government stability in Slovenia and Montenegro lies not in ideological heterogeneity/homogeneity, but in the importance of cleavages and their different dimensions dominating each society. While in Slovenia, alongside the most stable traditional-modern cleavage, several others have also emerged, in Montenegro the only 'frozen' statehood/nationhood cleavage (which in Slovenia is indeed a typical historical cleavage which no longer exists, Zajc - Boh 2004: 341) continues to provide both parties and voters with a simple and reliable cue for distinguishing which represents a viable political option.

\section{References}

Ágh, Atilla (1998): The Politics of Central Europe, Sage Publications.

Banović, Branko (2016): The Montenegrin warrior tradition: Questions and controversies over NATO membership, Palgrave Macmillan, New York.

Bartolini, Stefano - Mair, Peter (2007): Identity, competition and electoral availability: the stabilisation of European electorates 1885-1985, ECPR Press.

Baylis, Thomas A. (2007): Embattled Executives: Primer Ministerial Weakness in East Central Europe. Communist and Post-Communist Studies 40 (1): 81-106.

Bieber, Floarian (2013): The party system of Montenegro, in Strojanova, Vera, eds. Party politics in the Western Balkans, 139-150, Routledge. 
Benoit, Kenneth - Laver, Michael (2006): Party Policy in Modern Democracies, Routledge.

Blondel, Jean - Müller-Rommel, Ferdinand - Malova, Darina et al. (2007): Governing New European Democracies, Palgrave Macmillan.

Browne, Eric C. - Frendreis, John P. - Gleiber, Denis W. (1984): An 'Events' Approach to the Problem of Cabinet Stability. Comparative Political Studies 17 (2): 167-197.

Browne, Eric C. - Frendreis, John P. - Gleiber, Denis W. (1986): The Process of Cabinet Dissolution: An Exponential Model of Duration and Stability in Western Democracies. American Journal for Political Science 30 (3): 628-650.

Browne, Eric C. - Frendreis, John P. - Gleiber, Denis W. (1988): Contending Models of Cabinet Stability. American Political Science Review 82 (3): 930-941.

Casal Bertoa, Fernando (2014): Party Systems and Cleavage Structures Revisited: A Sociological Explanation of Party System Institutionalization in East Central Europe. Party Politics 20 (1): 16-36.

Cioffi-Revilla, Claudio (1984): The Political Reliability of Italian Governments: An Exponential Survival Model. American Political Science Review 78 (2): 318-337.

Conrad, Courtenay Ryals - Golder, Sona N. (2010): Measuring Government Duration and Stability in Central Eastern European Democracies. European Journal of Political Research 49 (1): 119-150.

Darmanović, Srđan (1992): Montenegro: Destiny of a satellite state. East European Reporter 27: 27-29.

Darmanovic, Srđan (2003): Montenegro: The dilemmas of a small Republic. Journal of Democracy 14 (1): 145-153.

Darmanović, Srđan (2007): Duga tranzicija u Crnoj Gori-od polukompetitivnih izbora do izborne demokratije, in Pavićević, Veselin - Darmanović, Srđan - Komar, Olivera - Vujović Zlatko, eds., Izbori i izborno zakonodavstvo u Crnoj Gori od 1990 do 2006, 83-101, CEMI.

Deegan-Krause, Kevin (2013): Full and Partial Cleavages, in Berglund, Sten - Ekman, JoakimDeegan-Krause, Kevin - Knutsen, Terje, eds., The Handbook of Political Change in Eastern Europe, 35-50, Edward Elgar Publishing.

Džankić, Jelena (2013): Cutting the mists of the Black Mountain: Cleavages in Montenegro's divide over statehood and identity. Nationalities Papers 41 (3): 412-430.

Fink-Hafner, Danica (2001): Politične stranke, Fakulteta za družbene vede, Ljubljana.

Fink-Hafner, Danica (2006): Slovenia: Betweeen Bipolarity and Broad Coalition-Building, in Jungerstam-Mulders, Susanne, ed., Post-Communist EU Member States: Parties and Party Systems, 203-31, Ashgate.

Fink-Hafner, Danica (2012): Značilnosti razvoja strankarskega sistema v Sloveniji, in Prunk, Janko - Deželan, Tomaž, eds., Dvajset let slovenske države, 193-213, Aristej, Maribor.

Fink-Hafner, Danica - Krašovec, Alenka (2006): Ideološko-politički rascjepi u Slovenskoj stranački areni poslije 1989. godine, in Fink-Hafner, Danica - Pejanović, Mirko, eds., Razvoj političkog pluralizma u Sloveniji i Bosni i Hercegovini, 71-104, Promocult - Fakulteta za družbene vede, Sarajevo, Ljubljana. 
Fink Hafner, Danica - Lajh, Damjan (2003). Managing Europe From Home: The Europeanisation of the Slovenian Core Executive, Fakulteta za družbene vede, Ljubljana.

Fink-Hafner, Danica - Novak, Meta - Knep, Matej (2017): Razvoj slovenskih zelenih strank v primerjalni perspektivi, Fakulteta za družbene vede, Ljubljana.

Goati, Vladimir (2008): Političke partije i partijski sistemi, Fakultet političkih nauka, Univerzitet Crne Gore.

Goati, Vladimir (2013): Izbori u Srbiji i Crnoj Gori od 1990. do 2013. i u SRJ od 1992. do 2003, Centar za Slobodne Izbore i Demokratiju-CeSID.

Goati, Vladimir - Darmanović, Srđan, ed. (2015): Izborni i partijski sistem u Crnoj Gori: perspektiva razvoja unutarpartijske demokratije, CEMI.

Grofman, Bernard (1989): The Comparative Analysis of Coalition Formation and Duration: Distinguishing Between-Country and Within-Country Effects. British Journal of Political Science 19 (2): 291-302.

Grofman, Bernard - van Roozendaal, Peter (1997): Modelling Durability and Termination. British Journal of Political Science 27 (3): 419-451.

Grotz, Florian - Weber, Till (2012): Party Systems and Government Stability in Central and Eastern Europe. World Politics 64 (4): 699-740.

Haughton, Tim, ed. (2009): Does EU Membership Matter? Party Politics in Central and Eastern Europe. The Journal of Communist Studies and Transition Politics 25 (4): special issue.

Haughton, Timothy - Krašovec, Alenka (2013): The 2011 Parliamentary Elections in Slovenia. Electoral Studies 32 (1): 201-204.

Haughton, Tim - Krašovec, Alenka (2014). Are European Elections Ever About Europe? The Washington Post: available at http://www.washingtonpost.com/blogs/monkey-cage/ wp/2014/05/23/european-parliamentary-elections-slovenia/ (10 May 2016).

Haughton, Timothy - Krašovec, Alenka (2018): Etablirana privlačnost novoga: Slovenski parlamentarni izbori 2018. godine. Političke analize 9 (33/34): 3-7.

Horowitz, Donald L. (1993): The challenge of ethnic conflict: democracy in divided societies. Journal of democracy 4 (4):18-38.

Huber, John D. (1998): How Does Cabinet Instability Affect Political Performance? Portfolio Volatility and Health Care Cost Containment in Parliamentary Democracies. American Political Science Review 92 (3): 577-591.

Hloušek, Vit - Kaniok, Petr, eds. (2020): European Parliament Election of 2019 in East-Central Europe: Second-Order Euroscepticism, Palgrave Macmillan.

Johannsen, Lars - Krašovec, Alenka (2017): Democratic Critique and Development: In Search for Responsiveness. Teorija in praksa 54 (posebna številka): 45-59.

Keman, Hans (2006): Parties and Government: Features of Governing in Representative Democracies, in Katz, Richard S. - Crotty, William, eds., Handbook of Party Politics, 160-174, Sage Publications. 
King, Gary - Alt, James E. - Burns, Nancy - Laver, Michael (1990): A Unified Model of Cabinet Dissolution in Parliamentary Democracies. American Journal of Political Science 34 (3): 846-871.

Kitschelt, Herbert (1995): Formation of Party Cleavages in Post-Communist Democracies: Theoretical Propositions. Party politics 1(4): 447-472.

Kitschelt, Herbert (2000): Linkages between citizens and politicians in democratic politics. Comparative political studies 33(6-7): 845-879.

Kitschelt, Herbert - Mansfeldova, Zdenka - Markowski, Radoslaw - Toka, Gabor (1999): Post-Communist Party Systems, Cambridge University Press.

Kolarič, Zinka (2012): Dvajset let postopnega spreminjanja slovenske socialne države, in Prunk, Janko - Deželan, Tomaž, eds., Dvajset let slovenske države, 283-298, Aristej, Maribor.

Komar, Olivera - Živković, Slaven (2016): Montenegro: A democracy without alternations. East European Politics and Societies 30 (4): 785-804.

Krašovec, Alenka (1996): Socialdemokratski stranki v Sloveniji (SDSS in ZLSD) v obdobju 1989 -1996. Diplomsko delo, Fakulteta za družbene vede, Ljubljana.

Krašovec, Alenka (2013): Slovenia, in Waele, Jean-Michel de - Escalona, Fabien - Vieira, Mathieu, eds., The Palgrave Handbook of Social Democracy in the European Union, 575-590, Palgrave Macmillan.

Krašovec, Alenka - Haughton, Tim (2011): Money, Organization and the State: The Partial Cartelization of Party Politics in Slovenia. Communist and Post-Communist Studies 44 (3): 199-209.

Krašovec, Alenka - Haughton, Timothy (2014): Privlačnost novog: Nove stranke i promjena stranačkog sustava u Sloveniji. Političke analize 5 (19): 48-53.

Krašovec, Alenka - Krpič, Tomaž (2019a): Naj ostanem ali grem? Vladne koalicije in koalicijski sporazumi v Sloveniji med letoma 1990 in 2018. Teorija in praksa 56 (1): 245-262.

Krašovec, Alenka - Krpič, Tomaž (2019b): Slovenia: Majority Coalitions and the Strategy of Dropping out of Cabinet, in Bergman, Torbjörn - Ilonszki, Gabriella - Müller, Wolfgang C., eds., Coalition Governance in Central Eastern Europe, 475-521, Oxford University Press.

Krašovec, Alenka - Lajh, Damjan - Kustec Lipicer, Simona (2006): The European Union and Party Politics in Slovenia: An Apparent or Real Impact?, in Lewis, Paul G. - Mansfeldova, Zdenka, eds., The European Union and Party Politics in Central and Eastern Europe, 169-189, Palgrave Macmillan.

Krašovec, Alenka - Lajh, Damjan (2009): The European Union: A Joker of Just an Ordinary Playing Card for Slovenian Political Parties? Journal of Communist Studies and Tranistion Politics 25 (4): 491-512.

Krašovec, Alenka - Lajh, Damjan (2020): Slovenia, in Hloušek, Vit - Kaniok, Petr, eds. European Parliament Election of 2019 in East-Central Europe: Second-Order Euroscepticism, 253-275, Palgrave Macmillan.

Krašovec, Alenka - Ramet, Sabrina P. (2017): Liberal Democracy in Slovenia: From Seventh Heaven to the Lobby of Hell in Only Two Decades?, in Ramet, Sabrina P. - Hassenstab, Christine M. - Listhaug, Ola, eds., Building Democracy in the Yugoslav Successor States: Accomplishments, Setbacks, Challenges since 1990, 256-286, Cambridge University Press. 
Kriesi, Hanspeter - Grande, Edgar - Dolezal, Martin - Helbling, Marc - Höglinger, Dominic Hutter, Swen - Wüest, Bruno, ed. (2012): Political Conflict in Western Europe, Cambridge University Press.

Lipset, Seymour M. - Rokkan, Stein (1967): Cleavage Structures, Party Systems and Voter Alignments: An Introduction, in Lipset, Seymour M. - Rokkan, Stein, eds., Party Systems and Voter Alignments, 1-64, The Free Press.

Laver, Michael - Shepsle, Kenneth A. (1996): Making and Breaking Governments, Cambridge University Press.

Lewis, Paul G. - Mansfeldova, Zdenka, eds. (2006): The European Union and Party Politics in Central and Eastern Europe, Palgrave Macmillan.

Lewis, Paul G. - Markowski, Radoslaw, eds. (2011): Europeanising Party Politics? Comparative Perspective on Central and Eastern Europe, Manchester University Press.

Mair, Peter (2006): Cleavages, in Katz, Richard S. - Crotty, William, eds., Handbook of Party Politics, 371-375, Sage Publications.

Malnar, Brina (2012): Neenakosti v družbi: ali statistika laže? Slovensko javno mnenje. Blog za navdušence nad javnomnenjskimi podatki: available at http://brinolina.blogspot.si/2012/06/ neenakosti-v-druzbi-ali-statistika-laze.html (10 August 2012).

Morrison, Kenneth (2009): Montenegro: A Modern History. London and New York: IB Tauris.

Müller, Wolfgang C. - Strøm, Kaare, eds. (2000): Coalition Governments in Europe, Oxford University Press.

Müller-Rommel, Ferdinand (2005): Types of Cabinet Durability in Central Eastern Europe: available at https://escholarship.org/uc/item/8cv4134w (14 June 2019).

Pavićević, Veselin - Darmanović, Srđan - Komar, Olivera - Vujović, Zlatko, ed. (2007): Izbori i izborno zakonodavstvo u Crnoj Gori 1990-2006, CEMI.

Pavlović, Srđa (2003): Who are Montenegrins? Statehood, identity, and civic society, in Beiber, Florian, eds., Montenegro in transition: Problems of identity and statehood, 83-106, Baden-Baden: Nomos.

Pavlovic, Srđa (2008): Balkan Anschluss: The Annexation of Montenegro and the Creation of the Common South Slavic State, Purdue University Press.

Pettit, Robin T. (2014): Contemporary Party Politics, Palgrave Macmillan.

Pikalo, Jernej (2000): Vrnitev (ali samo) vztrajanje levice na Slovenskem, in Fink-Hafner, Danica Haček, Miro, eds., Demokratični prehodi I., 203-210, Fakulteta za družbene vede, Ljubljana.

Popović, Milorad (2011): Njegoš i crnogorska nacija. Otvoreni kulturni forum. Cetinje.

Prunk, Janko (1992): Slovenski narodni vzpon, DZS, Ljubljana.

Prunk, Janko (2012): Politično življenje v samostojni Sloveniji, in Prunk, Janko - Deželan, Tomaž, eds., Dvajset let slovenske države, 17-56, Aristej, Maribor.

Saalfeld, Thomas (2008): Institutions, Chances, and Choices: The Dynamics of Cabinet Survival, in Strøm, Kaare - Müller, Wolfgang C. - Bergman, Torbjörn, eds., Cabinets and Coalition Bargaining: The Democratic Life Cycle in Western Europe, 327-368, Oxford University Press. 
Sartori, Giovanni (2005): Parties and party systems: A framework for analysis. ECPR press.

Somer-Topcu, Zeynep - Williams, Laron K. (2008): Survival of the Fittest? Cabinet Duration in Postcommunist Europe. Comparative Politics 40 (3): 313-329.

Stankov, Nemanja (2019): Springing up Like Mushrooms After the Rain: New Parties in Montenegro's Institutionalised Party System. Politics in Central Europe 15 (1): 163-185.

Stanojević, Miroslav - Krašovec, Alenka (2011): Slovenia: Social Pacts and

Political Exchange, in Avdagić, Sabina - Rhodes, Martin - Visser, Jelle, eds.,

Social Pacts in Europe: Emergence, Evolution, and Institutionalization, 232-

256, Oxford University Press.

Szczerbiak, Aleks - Taggart, Paul, eds. (2008). Opposing Europe: The Comparative Party Politics of Euroscepticism, Oxford University Press

Tzelgov, Eitan (2011): Communist Successor Parties and Government Survival in Central Eastern Europe. European Journal of Political Research 50 (4): 530-558.

Vehovar, Urban (1991): H koncu egalitarnega sindroma. Diplomsko delo, Fakulteta za družbene vede, Ljubljana.

Vehovar, Urban (1996): Družbeni razcepi in politične stranke na Slovenskem. Magistrsko delo, Fakulteta za družbene vede, Ljubljana.

Vehovar, Urban (2012): Slovenija, arhipelag obmodernosti, in Prunk, Janko - Deželan, Tomaž, eds., Dvajset let slovenske države, 81-111, Aristej, Maribor.

Vuković, Ivan (2015): Political dynamics of the post-communist Montenegro: one-party show. Democratization 22 (1): 73-91.

Vuković, Ivan - Batrićević, Nemanja (2020): Party Politics in Montenegro: In the Shadow of the Statehood Issue. forthcoming in Bertoa, Fernando - Dumont, Patrick, eds., Party Politics in Microstates, Routledge.

Zajc, Drago (2004): Razvoj parlamentarizma: funkcije sodobnih parlamentov, Fakulteta za družbene vede, Ljubljana.

Zajc, Drago (2009): Modeli oblikovanja koalicij in koalicijskih vlad v Sloveniji. Teorija in praksa 46 (4): 445-463.

Zajc, Drago - Boh, Tomaž (2004): Slovenia, in Berglund, Sten - Ekman, Joakim - Aarebrot, Frank H., eds., The Handbook of Political Change in Eastern Europe, 337-361, Edward Elgar.

Zver, Milan (2004): Value Systems and the Cleavage of the Party Space - EU and Slovenia, in Cabada, Ladislav - Krašovec, Alenka, eds., Europeanisaton of National Political Parties, 239-246, Fakulta humanitnich Studii ZČU, Plzen.

Warwick, Paul V. (1994): Governmental Survival in Parliamentary Democracies, Cambridge University Press.

Whitefield, Stephen (2002): Political Cleavages and Post-Communist Politics. Annual Review of Political Science 5 (1): 181-200. 
Alenka Krašovec is professor of political science at the Faculty of Social Sciences, University of Ljubljana, Slovenia. Address: Alenka Krašovec, Faculty of Social Sciences, University of Ljubljana, Kardeljeva pl. 5, 1000 Ljubljana, Slovenia. E-mail: alenka.krasovec@fdv.uni-lj.si

Nemanja Batrićević is a teaching assistant at the Faculty of Political Science, University of Montenegro, Montenegro. Address: Nemanja Batrićević, Faculty of Political Science, University of Montenegro, 13. jula br. 2, 81000 Podgorica, Montenegro. E-mail: nemanja.b@ucg.ac.me 